\title{
THE EFFORTS BY STARBUCKS COFFEE GRAHA PENA TO IMPROVE THE QUALITY OF EMPLOYEE PERFORMANCE
}

\author{
Wirawan Rizky Surya \\ Postgraduate School, University of Airlangga, Indonesia \\ E-mail: suryawirawanrizky@gmail.com
}

\begin{abstract}
Research aims to understand the attempt of starbucks coffee to increase the quality of employee performance. The data used is primary and secondary data. Primary data through quistioner deployed in Starbucks Coffee, while secondary data was sourced from the text, journals containing research and and the theory is still relevant to the about training and performance and also through website onlineBased on the research, conducted by researchers it can be concluded that efforts attempts to Starbucks Coffee Graha Pena Surabaya to increase the quality of factors of employee performance through viewed through education and also training, the results show the size of the relationship in general. So as to get labor or employees and strong in character, so human resources in company must recruiting employees work in a selective manner to fit to the job description and job specification. The company is also must be able to build leaders, coordinates and directs consistent with the objectives of the company employees. In addition to the age of the education and training is also very much to be considered, since the education level of also determines in patterns of thought and the decision making of a problem. Improving the performance of training will employees can be transferred to very good.So the conclusion is from his factor performance, that the training was needed to improve the quality of employee performance however, must also needs to be improved also other factors, the education to increase optimal performance to improve the quality of perfromance employees Starbucks Coffee Graha Pena Surabaya.
\end{abstract}

\section{KEY WORDS}

Training, education, quality, employee, performance.

One factor is a success the company employees. Any organization or institution in implementing the program directed always efficiently to accomplish a purpose companies. One way is to improve employee performance. Performance is basically nothing done or not done employees so that they affect how much they contribute to offices and organizations including service quality of being served. Strategy the increase in the performance is the way the company to improve their performance our employees to the purpose company can be achieved. Understanding other performance put forward by Payaman Simanjuntak (2005:1)suggested performance is the attainment of results for the implementation of the particular task. The company performance is the level of achievement of results in an effort to create the purpose company. Performance management is the whole activities undertaken to increase the company performance or organization, including performance each individual and working group in the company. So as to get labor or tens of thousands of workers who has the capability, you the ruling should a shortage of human resources in an enterprise must convene the work or tens of thousands of workers in a selective manner in order to comply with job which included description and job which included specification. The leaders of various Starbucks Coffee is also must be able to create character building of, coordinates and directs tens of thousands of workers consistent with the objectives of the company. It is really needed concerning this is because not all tens of thousands of workers event of new can directly in accordance with their needs. They need to be trained so as to be able to do the while their hearts tremble with effective to enhance the performance of the employees, the leaders of various necessary to hold an exercises and the development of tens of 
thousands of workers because it also is the is a way of effective for faced with a number of the barriers faced by many of the firms.

Starbucks was a company coffee and coffee shop global network from the united states headquartered in seattle, washington. Starbucks sell liquor hot and cold, coffee beans, salad, hot and cold sandwich, pastries sweet, a snack, glass and tumbler. Through division starbucks entertainment and brand hear music, the firm also has market books, music, and movie. Many of a company product seasonal nature or specific to the region where tavern stand. Ice cream and Starbucks Coffee also sold in grocery store performance problems this has happened to Starbucks Coffee Graha Pena Surabaya company in food and beverge from the united states open one branch in Indonesia precisely in surabaya. Pre when researchers conducted the study by means of direct observation or to Starbucks Coffee Graha Pena Surabaya on 15 february 2016, look a lot of workers who are doing human error when working in the operational example:

- There are still many taking order error to customers Starbucks;

- Lack of awareness of working in a co worker or team in a neighborhood in Starbucks Coffee Graha Pena Surabaya;

- Look employees could not run standard operational work which has been Starbucks Coffee Graha Pena Surabaya.

Strategy improving the quality of employee performance in Starbucks Coffee Graha Pena Surabaya is giving motivas to an employee, when there is an increase of work so employees should be given the task to follow learning and development the program and if after participate in training employees there is an increase of performance so employees will be given promotion. Training and development in Starbucks Surabaya one of them in the form of learning and development program advantageous career long-term will help employees to more responsibility for large the time to come. Hence, part hrd need to design activities the activity of organizing and utilization of human resources for follow the developments operations in the company due to technological innovations. For example: developments in the use of system online or offline in an enterprise change needs type human resources. The training programs must be changed to conform to the program.

\section{METHODS OF RESEARCH}

So that research activities accomplished and in accordance with what is expected writer, then required data is objective and relevant data must be submitted with a headline writer because it is very important. The data obtained from Shendy Shagita HRD Starbucks Coffee Surabaya, consisting of 16 employees and 3 pic (partner in charge) 1 store manager, 2 Supervisors and 13 employees or barista. Data is the results of the research, nor number of facts. The decree of the Minister of the P and K no. 0259/u/1977 on 11 july 1977 stated that data is all the facts and figures that could be material to assemble information, while the results of data processing information is used to a need (Suharsimi Arikunto , 2002: 96). As for the kind of data that is used by a writer in research: A. Primary data and Secondary data.

As for technique data collection used by an author in research that is: Technique interview; Technique documentation; Technique observation.

Field data or raw data is the data collected when collecting data. Raw data to research this is in the form of oral, data written and photos. Verbal and written data were obtained by interviewing the sources or subject of study. Data of photo is data that serve described a thing, objects, and scene when observation and when collecting data. Data oral documented into the form of recording of sound, written on document into the shape of the or note research. Data the second is a raw data (field data) who been subjected to the process selection data.

In writing this report, the use writers technique descriptive analysis namely in collecting data with containing about the discussion, exposure to about something objects as the at a time. The use writers technique descriptive analysis is intended so as to obtain the image and data is systematic pertaining to strategy the increase in the performance employees so writer 
can process and provides the data a systematic, accurate and can be responsibilities the truth.

\section{RESULTS AND DISCUSSION}

The Efforts by Strabucks Coffee Graha Pena to Improve The Quality of Employee Performance. Basically a clerk in implementing the tasks that are imposed on expected to show a performance the best can indicated by the employee, in addition performance indicated by a clerk of course are influenced by various factor who important for an increase in piece of work, be the goal of the organization or agencies where the employee work.

Increasing the quality of employee performance against store is reflected in all its forms of maintenance activity, the programs of guidance and facility provision, services and other sources depending on which has been carried out a traffic congestion due to Strabucks Graha Pena Surabaya. By the support of the utilization of facilities and infrastructure that with information technology to alamoth probably the treble as well as human resources the court members around him and dedicated high it is hoped will able to realize some of the form stores the delivered to their satisfaction. For that reason it is, in their effort to increase the quality of of employee performance to customers of two private the traffic congestion due to a Starbucks Graha Pena Surabaya implemented a variety of programs running environment based programs.

Important for employees and it is an asset. Employees of quality will strongly support the success of an enterprise. As described above, that in order to create a high quality performance, the resources should be accompanied by employees who qualified also. For that reason, basic steps taken Starbucks Coffee Graha Pena Surabaya to increase the quality of performance is the human resources.

Improve the quality Employee of workers steps of which were the traffic congestion due to be taken in this event Starbucks Graha Pena Surabaya in order to improve the quality of the employees is through training, and capacity improvement of the tens of thousands of workers. Education and learning and development has the goal with taking care of, raising the standard of living to these very works of tens of thousands of workers, essentially and perfectly morally good tens of thousands of workers as well as for a long time for a new entry worke. For more details of the type of programs actually traning, learning and development that is in a Starbucks the traffic congestion due to Graha Pena Surabaya, is as follows:

Table 1 - Learning and Development Starbucks Coffee Graha Pena, July 2016

\begin{tabular}{|c|c|c|c|}
\hline NO & Learning and Development & Jumlah peserta & Time (days) \\
\hline 1 & District Manager Training Program & 1 & 2 \\
\hline 2 & Retail Management Training Program & 1 & 2 \\
\hline 3 & Shift Supervisior Training Program & 2 & 7 \\
\hline 4 & Barista Basic Training Program & 4 & 1 \\
\hline 5 & District Coffee Master & 1 & 1 \\
\hline 6 & District Coffee Meeting (DCM) & 2 & 1 \\
\hline 7 & Coffee Class & 5 & 2 \\
\hline
\end{tabular}

Source: Data base Basic Training Starbucks Coffee Graha Pena 2016.

The implementation of the program learning and development a Starbucks Coffee Graha Pena has been an outspoken critic of previous a scheduled. The sense that they were learning and development scheduled to be held every education needed by store is considered to be they are also required to. Parts of the participants learning and development also had already been determined so that all tens of thousands of workers have been able to take learning and development. By the presence of learning and development it is hoped that such could operate to augment insight into the subject of, those experiences within those years, knowledge and skills tens of thousands of workers. In addition, it was also hoped they by the presence of learning and development tens of thousands of workers a Starbucks Graha Pena will be able to reflect or have they taken in an irrational manner, 
innovative, having broad horizons in carrying out jobs and be able to address of problems that emerged in a Starbucks Graha Pena Surabaya.

Provide guidance on the formulation discipline tens of thousands of workers discipline of employees did is one of the keys to encourage other parties to the success of a company in the quality of of employee performance. When tens of thousands of workers do not have higher rates of a good disciplin, so the operational costs of the store also do not go well. For that reason it is, on work safety all companies the people knew now now their drinking place to always keep the discipline of the employees. But even though has no regulations that would provide rules designed to weed out the saying that is written, still few minor offenses that occurs, for example some who were late with a wide range of think of any reply, furthermore there are also various there were officials that is produced from it during working hours. But such as the late there are still tolerance origin lateness no more 5 - 10 minutes of an enthralling first, while for tens of thousands of workers that is produced from it during working hours also, with the exception of to affairs of duties without prior permission declared the company.

The welfare of labors is a very important thing.For when the welfare of labors fulfilled, expected that this will can help grow working spirit high on the employees.

In Starbucks Coffee Graha Pena Surabaya on a monthly basis. The amount of salary in each employee not depending on the level of the and his position. The application of salary in Starbucks Coffee Graha Pena Surabaya different from the provision on civil servant. The amount of salary employees determined by formulation: basic salary $x$ the coefficients salary + intensive. While the coefficients salary that determines is Starbucks Coffee Graha Pena Surabaya.

The assessment of the provision of apprasial it was distributed among tens of thousands of workers for the purpose of appreciate the handiwork of and services as well as of devotion and a feat that had been given to a Starbucks Graha Pena Surabaya. Award or a judgment rendered to an employee who is have always possessed the features of devotion and fidelity only one long enough to company.

Value of the allowance hang it up and retire besides giving basic salary and of the award presenting ceremony, Starbucks Graha Pena Surabaya also has given allowance hang it up and retire to his servants. Starbucks Graha Pena Surabaya revision in order to provide care of its employees who has reached the age of 55 years. But as for stipulations on the amount of a retirement of $75 \% \mathrm{x}$ the base of traders civil servants and employees of the principal amount. This applies to the when civil servants at the office who retires has reached more than 25 years. While for the civil servants who are while industry sector contributes 25 years of sick leave then the size of the prosentasenya less than $75 \%$.

BPJS Kesehatan dan BPJS Ketenagakerjaan

is not simply about the allowance for the employees, but also provided grants BPJS Kesehatan dan BPJS Ketenagakerjaan. BPJS Kesehatan said that health and employment does not only given to officials employee of Starbucks coffee Graha Pena Surabaya, but to the rest of the family, because bpjs employment are first of all personal for employees. The shape of bpjs to finance health treatment for concerned hospital, all cover by the company. While BPJS Ketenagakerjaan it is more to personal employees there are 3 program that was submitted by Starbucks Coffee Graha Pena Surabaya to cover employees if a result of various obstacles during travel to come home from work, namely JKM (death benefit schemes), worker injury (guarantee of safety work) and retirement benefits are days of old ).

Allowance the program on Starbucks Coffee Graha Pena Surabaya based in performance store concerned so the size of the additional incentives it is based on the achievement store, there are two categories that is in Starbucks Coffee Graha Pena Surabaya namely, customer voice and sales store and when basic salary out on dated 28 in month, salary intensive is out in the 15th of month.

The Efforts by Strabucks Coffee Graha Pena to Improve The Quality of Employee Performance. Increasing the quality of employee performance by strabucks coffee graha a pen surabaya started with the field of where by the employee human resources are the main elements of the process some of the form store. Hence, competence of employee 
performance to be set by precise knowledge based, expertise, skill, the attitudes and which needed. According to the existing data shows that the number of permanent workers at the factory owned by Strabucks Coffee Graha Pena Surabaya as much as 16 employees consisting of 3 PIC (partner in charge) such as 1 store manager, 2 supervisior and 13 an employee or a barista in the outlet of the. Of course by the number of employees owned would be an asset to a Starbucks Coffee Graha Pena Surabaya to be able to provide maximum service to each client.

Efforts Starbucks Coffee Graha Pena Surabaya improve the quality of them through learning and development is by sending employees to follow learning and development held by Starbucks Coffee Indonesia. Starbucks Coffee Graha Pena Surabaya do learning and development every 3 months and employees who will join the learning and development also is scheduled every employees will be able to attend training to increase and improve devotion, ability and skills service well technically and non technique to customers. Be evaluated by looking at the level of education tens of thousands of workers that is in a starbucks Graha Pena Surabaya on table built with the sweat, the number of tens of thousands of workers will be issued at a senior high school education for (senior high school is considered) is 1 civil servants that they employ, was followed by civil servants who have the education level of Bachelor Degree (S1) as many as 7 civil servants that they employ and the least number was is that the master degree (S2) that the others were twice 1 civil servants that they employ. According to this condition, it seems that the local employee who there still is quite adequate sumatra plantation tbk to manage companies of various fields such provision of this service. Because will be mostly employees still have higher rates of senior high school education for that the others were twice 40 tens of thousands of workers. An example of this was indirectly would hold up progress Starbucks Graha Pena Surabaya in the event that give the speed of services and in resolving a task as well as resolve the problems of the existence of what problems in the company.

Efforts have been done by Starbucks Graha Pena Surabaya to improve the quality of the source of its power tens of thousands of workers the process may only lead to be balanced. The level of education because they did not actually give full measure and weight give them a guarantee that support for violent attacks had skill more, that he has done and on the other hand. This is the reason why would be done learning and development to enhance the capacity of tens of thousands of workers technically and knowledge purposes. The uninhibited movement of that which is given by Starbucks Graha Pena Surabaya to an employee who is want to went on to study also is a business to improve the quality of tens of thousands of workers, as through the level of education also affect knowledge and way of thinking someone in taking decide for he is the some kind of trouble. So in other words, between their knowledge and skills also has to make it capable in do their duty.

Besides the ability and quality of employees being developed by Starbucks Coffee Graha Pena Surabaya, discipline employees also needs to be enhanced if employees Starbucks Coffee Graha Pena Surabaya has a low discipline will can affect the company. In order to create behavior and an employee supporting the creation of quality of service, and Starbucks Coffee Graha Pena Surabaya trying to continue to maintain discipline employees. The results of which have so far has been done suggests that the discipline employees would be good, especially with respect work hours office and hours home office. As well beside effort held also them through enforcement absentee and working hours so that employees all of which is really can take responsbilities all his actions. There was a limit of the boundaries that between the rights and obligations of our employees that had to met make the employees more disciplined in doing the work of their trusts. Through the discipline that high implementing a rules can be felt its benefit by all parties with the provisions that the rules it was made after taking into account the principle of justice and is beneficial to the interests of the public.

Other than an effort to improve the quality of services and discipline employees, other effort who also exercised is maintain the welfare of labors. To support the achievement company business created working conditions that can be make employee feel calm and take comfort in working is to provide welfare to employees. Given to officials of welfare 
should be based on on the quality of and according to government regulation and on the basis of the company capacit.However the form of a company, definitely not will ignore the well being of employees, because the welfare of labors would serve as a means of can increase a motivation in worked so as to be more productive and gives rise to loyalty employees of the company. Starbucks Coffee Graha Pena Surabaya in their bid to improve the welfare of employees did give various kinds of facilities for the employees that is salary, retirement benefit , BPJS Kesehatan.

\section{CONCLUSION}

So as to get labor or employees who capable, should a human resources in an enterprise must held the recruitment of labor or employees selectively to fit to the job description and job specification. Leaders the companies must be can build, coordinates and directs employees consistent with the objectives of company. Problems performance this has happened to Starbucks Coffee Graha Pena Surabaya is company in food and beverge from the united states opening of one its branches in Indonesia precisely in Surabaya. The improvement in the quality of employee performance in Starbucks Coffee Graha Pena Surabaya is motivating employees, if there is an increase in employees work and be assigned to follow learning and development program and if after an increase in employees participate in training performance so employees will be given a promotion. Training and development in Starbucks Surabaya one of learning and development programs that greatly benefits long term career that will help employees to greater responsibility in time to come.

Increasing the quality of employee performance against store is reflected in all its forms of maintenance activity, the programs of guidance and facility provision, services and other sources depending on which has been carried out Starbucks Graha Pena Surabaya. By the support of the utilization facilities and infrastructure that with information technology to alamoth probably the treble as well as human resources the court members around him and dedicated hoped will able to realize some of the form stores the delivered to their satisfaction. For that reason it is, in their effort to increase the quality of of employee performance to customers of Starbucks Graha Pena Surabaya implemented a variety of programs running environment based programs like:

Starbucks Coffee Graha Pena Surabaya in developing services and especially in human resources include increasing the quality of them through learning and development. An increase in discipline employees, and working the welfare of labors. It was done for encourages the creation of productivity employees. Step traveled Starbucks Coffee Graha Pena Surabaya to improve the quality of the employees is through training, and capacity building employees. Education and learning and development have aims to maintain, increase skill employees, even for old and new employees.

Discipline employees did is one of the keys to support the success of a company in the quality of employee performance. When employees not to have a good discipline, so operational store also cannot go with smooth. Hence, each company had rules its own to keep discipline the employees

In an organization, the welfare of employee is a very important thing. For when the welfare of labors fulfilled, expected that this will can help grow working spirit high on the employees, namely: the provision of salary; the provision of appraisal; allowance pension; BPJS Kesehatan and BPJS Ketenagakerjaan; allowance incentives.

Suggestions:

- To the process of recuitment employees shall put in standart high , to fit the criteria that is not only the process interview, but with test for example, potential academic, psychological test, etc.

- Used to minimize errors to customer, Stabucks not only supported a theory but will also done customer connection in continue against the employee got to know further taste customers will dating to store.

- The problem of education the past also should be in restrict, as most mindset children aged young especially fresh graduate and vocational senior high schools still not 
reflect in open minded. At least D3 or on it, can also graduates hospitality or experience in the field of coffee shop because this is concerning good services in the field of hospitality especially

- The process of learning and development have to be in have put a barrier it should also be noted continue so that when your words come true the regeneration of or at the time of turn over employee high to come to pass as back up to be carried out efficiently, paramedics are distributed to every disparities between senior to junior.

- Always be updated by waking early and going trying to agree schedule program of employee performance mostly street so that it may not left behind with a starbucks which were outside aboard.

\section{REFERENCES}

1. Arikunto, Suharsimi. 2002. Prosedur Penelitian Suatu Pembahasan. Jakarta: Bhineka Cipta.

2. Efendi, Marihot Tua. 2002. Manajemen Sumber Daya Manusia. Jakarta: Grasindo.

3. Veithzal Rivai. 2004. Manajemen Sumber Daya Manusia Untuk Perusahaan: Dari Teori Ke Praktik. PT. Raja Grafindo Persada, Jakarta.

4. Handoko, T. Hani. 2003. Manajemen Edisi 2. Yogyakarta: BPFE.

5. Hasibuan, Malayu. 2002. Manajemen Sumberdaya Manusia. Jakarta: Bumi Aksara.

6. Keraf, Gorrys. 2001. Komposisi. Flores: Nusa Indah.

7. Mangkunegara, Anwar Prabu. 2005. Manajemen Sumber Daya Perusahaan. Bandung: PT. Remaja Rosdakarya.

8. Marzuki. 2002. Metodelogi Riset. Yogyakarta: BPFE - EUII.

9. Notoatmodjo, Soekidjo. 2003. Pengembangan Sumber Daya Manusia. Jakarta: PT. Rineke Cipta.

10. Sulistiyani, Ambar. $T$ dan Rosidah. 2003. Manajemen Sumber Daya Manusia. Yogyakarta: Graha IImu.

11. Sumarni, Murti dan John Soeprihanto. 2000. Pengantar Bisnis. Yogyakarta: Liberty.

12. Sedarmayanti, 2009. Sumber Daya Manusia dan Produktivitas Kerja. Bandung: Mandar Maju. 